\title{
Intravascular Histiocytosis Associated with Bacterial Endocarditis
}

\author{
Intravaskuläre Histiozytose in Assoziation mit einer bakteriellen Endokarditis
}

Authors

Institutions
G. Linkeviciute' ${ }^{1}$, A. Petkevicius ${ }^{1}$, J. Makstiene ${ }^{2}$, I. Gudinaviciene ${ }^{2}$, S. Valiukeviciene ${ }^{1}$, G. Mahrle ${ }^{3}$

${ }^{1}$ Department of Skin and Venereal Diseases, Lithuanian University of Health Sciences, Medical Academy, Kaunas, Lithuania

${ }^{2}$ Department of Pathological Anatomy, Lithuanian University of Health Sciences, Medical Academy, Kaunas, Lithuania

3 Department of Dermatology and Venereology, University of Cologne, Germany
Bibliography

Dol http://dx.doi.org/

10.1055/s-0034-1377832

Akt Dermatol 2014; 40: 401-403

(c) Georg Thieme Verlag KG

Stuttgart · New York

ISSN 0340-2541

\section{Corresponding author}

\section{Gintare Linkeviciute}

Department of Skin

and Venereal Diseases

Lithuanian University

of Health Sciences

Eiveniu 2

LT - 3007, Kaunas

Lithuania

gintarelinkeviciute0@gmail.com

\section{Abstract \\ $\nabla$}

A 63-year-old woman presented with a 6-month history of malaise, fever, weight loss and violaceous indurated skin patches on her earlobes, elbows, knees, and upper arms. Based on clinical findings and positive Borrelia burgdorferi IgG antibodies, a diagnosis of an inflammatory-edematous stage of Acrodermatitis chronica atrophicans could not be excluded. After treatment with Cephalosporin for 3 weeks skin lesions reduced. However, malaise, fever, anemia, leukopenia, thrombocytopenia, and elevated amounts of CRP, ESR, liver enzymes remained. Skin histology and immunohistochemistry revealed vascular prolife-

\section{Case Report \\ $\nabla$}

A 63-year-old woman had a 6-month history of malaise, fever, and weight loss. Diabetes mellitus type II was diagnosed 16 years ago. Clinical examination showed symmetrical violaceous indurated patches on the skin of her earlobes, elbows, knees, and upper arms ( $\bullet$ Fig. $1 \mathbf{a}-\mathbf{c}$ ). Based on clinical findings and positive Borrelia burgdorferi IgG antibodies, a diagnosis of an inflammatoryedematous stage of Acrodermatitis chronica atrophicans could not be excluded. The patient was treated with Ceftriaxone $2 \mathrm{~g} /$ day for 5 days and Cefuroxime $1 \mathrm{~g} /$ day for 3 weeks. Skin lesions reduced, malaise and fever remained. Laboratory findings showed anemia, leukopenia, thrombocytopenia, elevated amounts of liver enzymes GGT 389IU/L; alkaline phosphatase $162 \mathrm{UI} / \mathrm{L}$; CRP $39 \mathrm{mg} / \mathrm{l}$, ESR $37 \mathrm{~mm} / \mathrm{h}$. Blood and urine cultures, immunological laboratory findings of systemic connective tissue diseases were negative. A biopsy of skin lesions was performed. Dermatohistopathology revealed vascular proliferation with dilated clusters of dermal capillaries partly occluded by cellular thrombi and large multiple hematopoietic intravascular cells positive for LCA ration with intravascular cells positive for LCA and marker of histiocytes CD68. According to clinical and immunohistochemical findings intravascular histiocytosis associated with infectious endocarditis was diagnosed. Transoesophageal heart sonography supported a diagnosis of infectious endocarditis. The patient was treated with Benzylpenicillin intravenously for 21 days. Heart valve replacement surgery was performed. Intravascular histiocytosis (IVH) is a rare reactive cutaneous lesion of unknown pathogenesis. A diagnosis of it may necessitate further clinical evaluation to exclude the possibility of co-existent systemic disease.

and negative for CD31, CD34, CD3, CD20, CD1a and S100 markers. The positivity of CD68 markers suggested a histiocytic origin of intravascular cells. D2-40 marker highlighted lymphatic vessels with no histiocytes inside ( $\bullet$ Fig. $2-7$ ). Clinical and histological findings led to a diagnosis of cutaneous intravascular histiocytosis. Abdominal ultrasound investigation showed dysmetabolic, enlarged liver and splenomegaly. Liver biopsy indicated reactive changes and periportal steatosis of hepatocytes. Transoesophageal heart sonography supported a diagnosis of infectious endocarditis which was verified after heart valve replacement surgery.

After treatment with Benzylpenicillin at 18.000.000 Units/day intravenously for 21 days skin lesions, fever and malaise improved. Heart valve replacement surgery was performed due to chronic active infectious endocarditis.

\section{Discussion \\ $\nabla$}

Intravascular histiocytosis (IVH) is a rare benign cutaneous disorder of unknown pathogenesis, characterized by a reactive intravascular dermal 

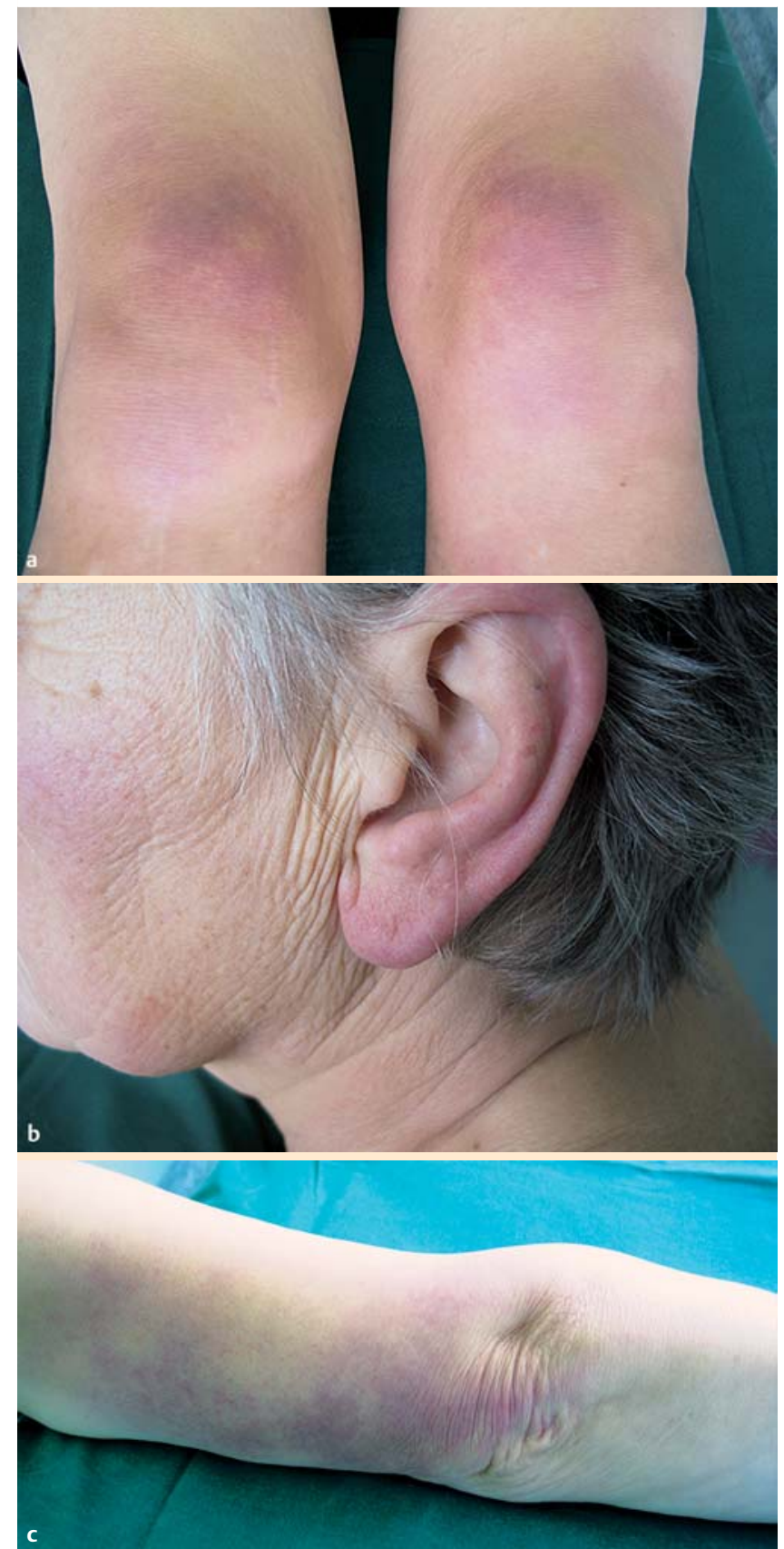

Fig. 1 Clinical view: Symmetrical violaceous skin patches on knees (a), earlobes (b) and elbows (c).

proliferation of histiocytes. This rare disease was firstly described in 1994 and named intravascular histiocytosis by O'Grady et al. [1]. Some authors described this condition as early stage of reactive angioendotheliomatosis (RAE) [2,3]. Subsequent authors proved the lymphatic nature of the ectatic vessels by demonstrating the expression of a lymphatic endothelial cell marker, podoplanin (D2-40). The condition has since been referred to as intralymphatic histiocytosis [4].

Bakr et al. report a total of 46 cases of IVH [4]. Most cases arise in patients with rheumatoid arthritis (RA) [4-13], tonsillitis [14], rheumatic fever [2], orthopedic metal implants [15], trombogenic diathesis and vulvar necrosis [16], colon carcinoma $[8,17]$, tuberculosis [17]. Some publications [2,3] refer that IVH can be associated with infectious endocarditis, but we could not find any properly documented cases reported in scientific data bases.
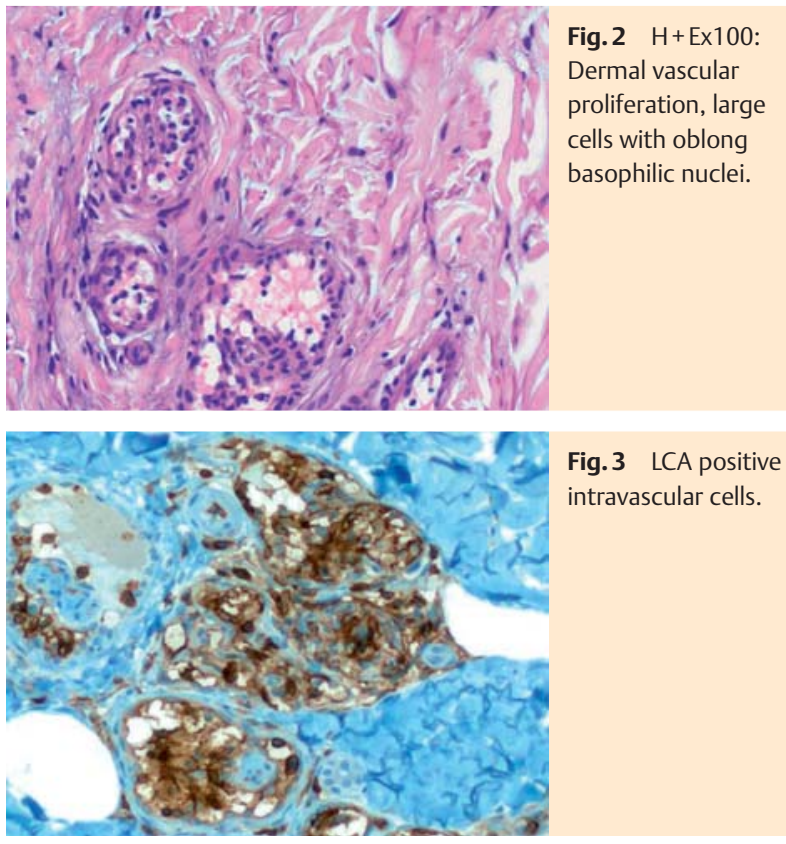

Fig. 3 LCA positive intravascular cells.

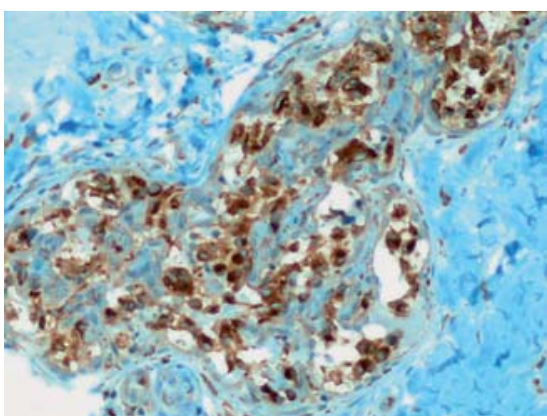

Fig. 4 CD68 positive intravascular cells.

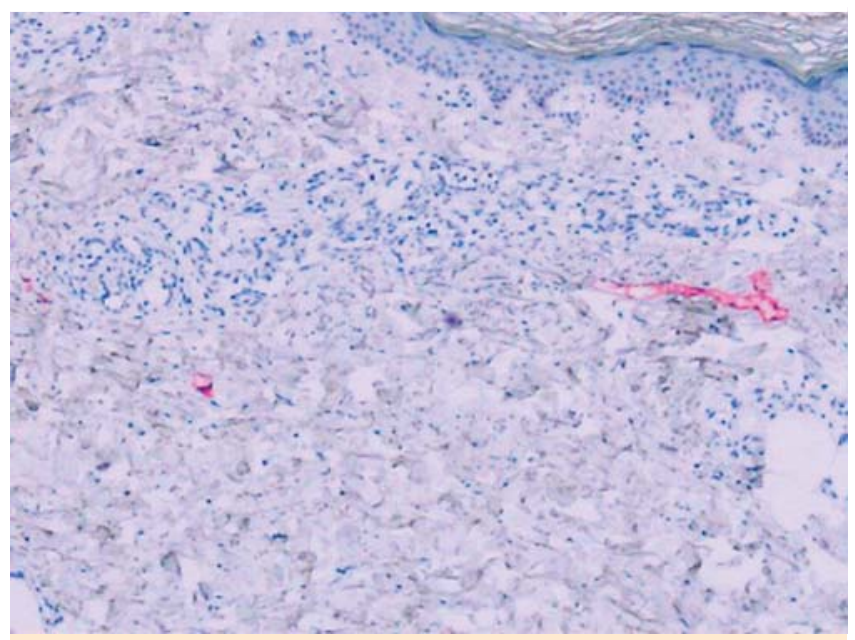

Fig.5 D2-40 marker highlights lymphatic vessels with no histiocytes inside.

The origin of this condition remains unclear. Requena et al. suggest chronic inflammation and the drainage of inflammatory mediators away from the synovium into lymphatic vessels by RA [5]. Okamoto et al. highlighted the potential role of tumor necrosis factor-alfa, an important mediator of inflammation in RA, which could potentially leak from inflamed joints causing the intralymphatic aggregation of macrophages. In support of this hypothesis, blockade of antitumor necrosis factor-alfa using infliximab has been shown to markedly improve the skin lesions 


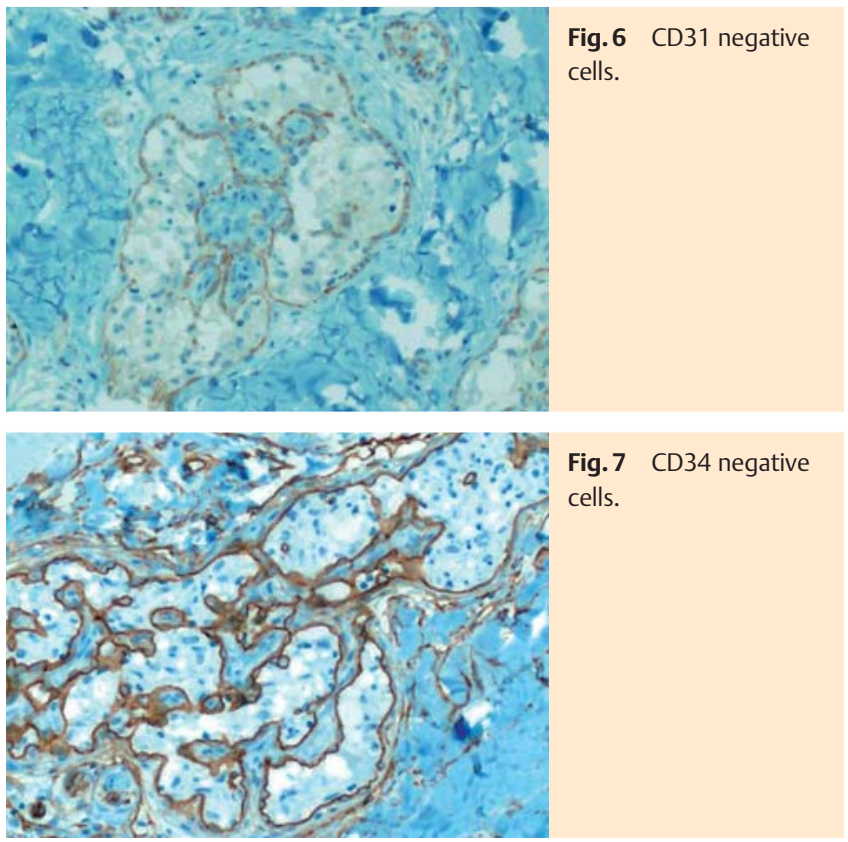

of IVH [6]. Further, IVH has been observed to regress after treatment of associated conditions [4].

In contrast to most reported cases of IVH, our patient had no clinical history or symptoms to suggest an associated rheumatoid arthritis. Also the dilated vessels with histiocytes were negative for monoclonal antibody D2-40.

The clinical presentation of IVH is characterized by poorly defined erythematous plaques, mainly on the limbs, sometimes in association with livedo reticularis or superficial papules, vesicles, or nodules [1-17].

Histopathologically, IVH is characterized by the proliferation of histiocytes in the dilated blood or lymphatic vessels [1 -17]. Histologic differential diagnosis should include angiosarcoma, malignant and reactive angioendotheliomatoses, intravascular lymphoma, Langerhans‘ cell histiocytosis. In our case CD31, CD34 markers, which highlight endothelial cells, were negative. Thus angiosarcoma, malignant and reactive angioendotheliomatoses were excluded. We ruled out lymphomas according to negative markers for CD3 and CD20, CD1a and S100. Negative intravascular cells do not fit for Langerhans' histiocytosis.

IVH is a rare reactive cutaneous lesion of unknown pathogenesis. Treatment of IVH is usually directed towards associated systemic illnesses. The diagnosis of IVH is important and may necessitate further clinical evaluation to exclude the possibility of co-existing autoimmune and infectious systemic disease.

\section{Conflict of interest}

$\nabla$

The authors declare no conflict of interest.

Zusammenfassung

\section{Intravaskuläre Histiozytose in Assoziation mit einer bakteriellen Endokarditis}

Eine 63-jährige Frau klagte bereits 6 Monate über andauernde allgemeine Schwäche, Fieber und Gewichtsverlust sowie rotblaue Hautstellen auf den Ohrläppchen, Ellenbogen, Oberarmen und Knien. Aufgrund der klinischen Symptome, des positiven Borrelia-burgdorferi-IgG-Tests und dem Verdacht auf Acrodermatitis chronica atrophicans wurde eine 3-wöchige Cephalosporin-Antibiotikum-Therapie durchgeführt. Im Anschluss hatten sich Hautläsionen gebessert, Episoden von Fieber, Anämie, Leukopenie, Thrombozytopenie, erhöhte CRP- und BSG-Werte sowie erhöhte Leberenzyme blieben aber bestehen. Bei histologischen und immunhistochemischen Untersuchungen der Läsionen zeigten sich vaskuläre Proliferationen mit den intravaskulär positiven LCA- und CD68-positiven Histiozyten, was zur Diagnose einer intravaskulären Histiozytose (IVH) führte. Mittels transösophagealer Echokardiografie konnte eine septische Endokarditis bestätigt werden. Die Patientin wurde intravenös mit Benzylpenicillin (21 Tage) und chirurgisch mit einem Herzklappenersatz behandelt. Eine IVH ist eine seltene Hautläsion mit unklarer Pathogenese. Bei der Diagnostik ist es sehr wichtig, auch andere assoziierte systemische Krankheiten auszuschließen.

\section{References}

1 O'Grady JT, Shahidullah $H$, Doherty VR et al. Intravascular Histiocytosis. Histopathology 1994; 24: 265 -268

2 Rieger E, Soyer HP, Leboit PE et al. Reactive angioendotheliomatosis or intravascular histiocytosis? An immunohistochemical and ultrastructural study in two cases of intravascular histiocytic cell proliferation. Br J Dermatol 1999; 140: 497 - 504

3 Mensing CH, Krengel S, Tronnier $M$ et al. Reactive angioendotheliomatosis: is it 'intravascular histiocytosis'? JEADV 2005; 19: 216-219

4 Bakr F, Webber N, Fassihi H et al. Primary and secondary intralymphatic histiocytosis. J Am Acad Dermatol 2014; 70: 927-933

5 Requena L, El-Shabrawi-Caelen L, Walsh SN et al. Intralymphatic histiocytosis. A clinicopathologic study of 16 cases. Am J Dermatopathol 2009; 31: $140-151$

6 Okamoto $N$, Tanioka M, Yamamoto $T$ et al. Intralymphatic histiocytosis associated with rheumatoid arthritis. Clin Exp Dermatol 2008; 33: $516-518$

7 Takiwaki $H$, Adachi A, Kohno $H$ et al. Intravascular or Intralymphatic Histiocytosis Associated with Rheumatoid Arthritis: A Report of 4 Cases. Am J Dermatopathol 2004; 50: 585-590

8 Borregón P, Avilés JA, Parra V. Erythematous-violaceous plaques on the limbs of a patient with rheumatoid arthritis and colon cancer. Actas Dermosifiliogr 2012; 103: 543-544

9 Huang HY, Liang CW, Hu SL et al. Cutaneous intravascular histiocytosis associated with rheumatoid arthritis: a case report and review of the literature. Clin Exp Dermatol 2009; 34: 302 - 303

10 Türk NŞ, Demirkan NÇ, Taşh L et al. Intravascular histiocytosis associated with rheumatoid arthritis. Pam Med J 2013; 6: 92 - 95

11 Catalina-Fernández I, Alvárez AC, Martin FC et al. Cutaneous intralymphatic histiocytosis associated with rheumatoid arthritis: report of a case and review of the literature. Am J Dermatopathol 2007; 29: $165-168$

12 Okazaki A, Asada H, Niizeki $H$ et al. Intravascular histiocytosis associated with rheumatoid arthritis: report of a case with lymphatic endothelial proliferation. Br J Dermatol 2005; 152: 1385 - 1387

13 Kaneko T, Takeuchi S, Nakano H et al. Intralymphatic Histiocytosis with Rheumatoid Arthritis: Possible Association with the Joint Involvement. SciRes. Case Reports in Clinical Medicine 2014; 3: 149-152

14 Asagoe $K$, Torigoe $R$, Ofuji $R$ et al. Reactive intravascular histiocytosis associated with tonsillitis. Br J Dermatol 2006; 154: 560-563

15 Hassan Ibrahim A, Pullmann S, Assaf C et al. Intralymphatic Histiocytosis following Orthopaedic Metal Implant. Akt Dermatol 2013; 39: $328-331$

16 Pouryazdanparast $P, Y u$ L, Dalton VK et al. Intravascular histiocytosis presenting with extensive vulvar necrosis. J Cutan Pathol 2009; 36: $1-7$

17 Echeverría-García B, Botella-Estrada R, Requena $C$ et al. Intralymphatic histiocytosis and cancer of the colon. Actas Dermosifiliogr 2010; 101: $257-262$ 